\title{
A Comparison of fantacy-reality contradiction and melancholy themes in the works by Tevfik Fikret and Ahmet Tevfik, the first Turkish story- writer in Cyprus
}

\author{
Şevket Öznur ${ }^{1, *}$ \\ ${ }^{1}$ Near East University, Faculty of Arts and Sciences, Turkish Language and Literature, Nicosia- \\ 99138, North Cyprus
}

\begin{abstract}
The people representing Servet-i Fünun do not attend to social issues. They lock themselves in the house and are mostly interested in the nature and people they feel sorry about. The poets and writers of Servet-i Fünun literatures adapted Western literature and influenced many writers and poets of their time and later times by some changes in style, theme, and wording. The best sample of this interaction in literary periods can be observed in the comparative Works by the same community in different areas. In this study, a theme comparison will be done between the Work by Tevfik Fikret and the Turkish Cypriot writer and the theme interaction in Turkish Literature will be finalized. Tevfik Fikret is appointed as the Editor-in-chief of the Scientific and Science Journal. Then he converts the journal into Literature Journal and gathers young people around it. The Servet-i Fünun people use an arty language, peculiar to them, in expressing feelings and thoughts down to the last detail with ample images and characters. Most of the Servet-i Fünun writers and poets were raised in the same educational institutions, experienced the same political, social, and financial conditions, were engaged in the same issues, were almost at the same age generation from the middle-class, were educated in Western schools and with good knowledge of foreign languages. Naturally, these similarities created a common joy and culture among them. These writers and poets believed in strong family bonds and would take up the same motives when they were together to talk about literature issues. They influenced many writers and poets. Pessimism and tediousness, the basis of literature, became the main starting points for the whole literature. In his many poems, Tevfik Fikret treated compassion and reflected the grief of many poor and lonely people. In the 1970s Turkey adapted Western Literature type but this type of literature was introduced to Cyprus late, not before the 1890s. Even though, the Servet-i Fünun followers began to influence the literateurs and their Works in Cyprus. Soon after the British era in 1878 in Cyprus, tension between Moslem Turk and Christian Greek communities started to increase. In 1901, Ahmet Tevfik published the "Mir'at-1 Zaman" and in 1909 the "Kokonoz" newspapers. A fundamental change in the literature came about particularly when these newspapers
\end{abstract}

\footnotetext{
*Corresponding author: sevket.oznur@neu.edu.tr
} 
were published in Cyprus. Tevfik Fikret brought up his views and his feelings about life in an allergoric and symbolic way. In both Works, the themes were full of pessimism and melancholy. While T. Fikret emphasized the fantasy-reality contradictions and the difference between thoughts and personalities of two lovers, the melancholy-pessimism theme was the priority in Ahmet Tevfik Efendi's work. In both works, the nature was explained with pessimism and melancholy and was symbolized as the place of love. The Servet-i Fünun followers were a family. Even more, it is emphasized that, in some Works the main characters are the writers and poets themselves. The Servet-i Fünun followers were effective in Abdülhamid II era, during which there was a pressure on the poets and writers. The pressure and censure took the writers and poets away from social issues and made them busy with an individual, pessimistic and sickly literature. This is why, melancholy and its analysis was amply mentioned in their Works. Turkish Story-writing started in 1897 in Cyprus. Ahmet Tevfik, who was in Istanbul then, was influenced by the Servet-i Fünun followers and took them as a model in his Works. They were strongly bound to the principles of arts. Although everything could be a topic for poems, but due to the political pressure of the day, they limited their Works to love, nature, family-life, and simple current issues. As the aim, the themes by the two writers will be compared and important parts of comparative studies in Turkish literature will be dealt with, to open a way to different comparisons.

\section{Introduction}

Arguments about traditional and contemporary literature went on for a long time and in the end the writers and poets who adapted contemporary literature began to discuss the issue among themselves. The problems created by these discussions were the groundwork for a new era. In 1895, Recaizade Mahmut Ekrem argues that "rhyme" is not visual, but audio and after long discussions of "fantacy-reality", he decides to establish a new magazine to advocate new ideas in literature. He appoints Tevfik Fikret as the author-inchief of the Servet-i Fünun, a science magazine. Later, he names the magazine as "Literature Magazine" and calls the young genetation to suport it. In this new literature era, Halit Ziya Uşaklıgil, Tevfik Fikret, Cenab Şahabettin, Ahmet Şuayip, Mehmet Rauf, and Hüseyin Cahit Yalçın are the chief-representatives and Müftüoğlu Ahmet Fikret, Ali Ekrem, İsmail Safa, Faik Ali, Celal Sahir, Süleyman Nazif, Ahmet Reşit, Hüseyin Suat Safveti Ziya, Hüseyin Siyret, Safvet Nezihi, Ali Nusret [3], İsak Ferrera, an Ottoman Citizen, and Avram Naon are the representatives in the second or third places [6]. Nurettin Ferruh, a poet in Servet-i Fünun era, is always active in press, but kept in the background of the top poets or writers, brings up changes in style in poetry. He oficially registers his book called, "Şafak Sadaları" and his articles before the Servet-i Fünun era. The book "Şafak Sadaları", written before 1985, becomes an important source in terms of style in poetry for the Servet-i Fünun followers [8].

According to İsmail Parlatır, the themes of Servet-i Fünun are mostly fantasy-reality contradictions, running away, committing suicide, taking a shelter in the nature, and shedding tears. These themes have sub-motives. Tedium: Sadness, Pessimism: Melancholy, Broken-heart, broken stringed instrument-Rübab simile, Blind-love-Garam, Youth, Time concept and elapse of time, Art, Poetry, Natural Views, Imagination and disappointment Soul and Unhealthy soul, Love, Philosophy, Mercy, Brothers, Family and 
home, Wicked life, Flying- Wish to be a bird, Unrevealed feeling of freedom, Death- grave, Homeland and portraits [4].

The Servet-i Fünun magazine, first published in (1886) is closed in 1901. However the influence of this new literature lasts until 1914, the beginning of World War 1. Tevfik Fikret, the author-in-chief of the Servet-i Fünun magazine and the poet with the best examples of poems dies in 1915. He influences many writers and poets. The basics of his literature, pessimism and melancholy become the foundation of a literature. T.Fikret writes several poems in which he deals with sadness and worries about poor and homeless people. Before he starts for the magazine, he writes poems in old style. In 1893-1895, he discovers his own style and becomes more confident of himself. French poetry and Western writers help him find his own style. He can not travel particularly to remote places and this strengthens fantacy-reality contradictions in his poems. He writes the book "Rübab-1 Şikeste" between 1986-1900. The theme "fantacy and reality contradictions" in the poem "Süha and Pervin", in his book, is the topic. He also includes the nature, love, and pessimism in his motives [3].

\subsection{The first works of contemporary Turkish literature in Cyprus}

Turkey adapted Western type of literature in the 1870s, but its reflection in Cyprus was not before the 1890s. Even though, from 1890 onwards, the Servet-i Fünun followers were able to influence the litereteurs and their works. After 1878, clashes between the Moslem Turk and Christian Greek communities gradually became more severe. In 1883, Aşık Kenzi produced one of the most beautiful examples of folk-poems called "Cyprus Epic". In 1901, Ahmed Tevfik published "Mir'at-1 Zaman" and in 1909 "Kokonoz" newspapers. Fundamental changes happened in literature particularly when publishing newspapers started in Cyprus. Kaytazzade Mehmet Nazım wrote the first examples of poems in Western style. Ahmet Tevfik is the following important name followed by Urkiye Mine Balman, Engin Gönül, Pembe Marmara, Osman Türkay, Özker Yaşın, Nazif Süleyman Ebeoğlu, Semih Sami Umar, and Necla Salih Suphi in the British Colonial period. Kaytazzade Mehmet Nazım, one of the youngsters raised by Namık Kemal, produced his first work called "Yadigar-1 Muhabbet" in 1896. The first novel "İntibah" was writing in Cyprus by Namık Kemal during his detention on the island. Following this, Hikmet Afif Mapolar had a great influence on the Cyprus Turkish literature by publishing his novels and stories, some of which are; "Kahraman Kaplan" (1936), "Son Damla" (1937), "Diken Çiçeği” (1938), "Son Çıldırış" (1939), and "Kendime Dönüyorum" (1943). The first theatres were "Hicran-1 Ebedi" written in 1895 and "Safa" or "Netice-i İptila" by Kaytazzade Mehmet Nazım . Namık Kemal "Vatan yahut Silistre" play was on the stage 20 years after his death, as the first local play on stage in Cyprus. Following min Nihat Bey's Müsameret-name", one of the first most important stories was " Bir Manzara-i Dil-Güşa” by Ahmet Tevfik Efendi in 1897, which is also assumed as the beginning of Turkish story writing in Cyprus. Ahmet Tevfik, in Istanbul on those days, is influenced by the Servet-i Fünun followers and takes them as the model in his writings. The first story book is "Gülünçlü İbret-amiz Hikayeler", written by Ahmed Nuri Müdürzade, in 1908. This is followed by the long story "Son Çıldırış" by Hikmet Afif Mapolar, in 1939 [7]. 


\section{A comparative study of Süha and Pervin and Bir Manzara-i Dil Güşa}

\subsection{Thematic study 1: Ahmed Tevfik Efendi’s story "Bir Manzara-i Dil Güşa"}

We overviewed A.Tevfik Efendi's themes and motives in his story "Bir manzara-i DilGüşa" and noticed he mostly emphasized Pessimism and melancholy and conveyed this to his reader through the nature. He presented the motive of nature intermingled with pessimism. Below are some examples from the story;

It was a lively time in Spring. The shining moon glistened the world with its dazzling light going through the branches of every tree making new leaves look like embroidered with silver wire [2].

This is the introduction part of the text. The scene of the nature is used describe the spring motive with the darkness.

She was in her late fourteens, but the change on her shining face reflected the signs of a strong ongoing anxiety in her heart.

Angel is the girl in the story, still in her late fourteens, which displays the beauty and the motives of young age.

The dinner- bell rings to invite the households to dinner. The girl, once more, looks at herself admiringly in the mirror for the final touches and walks out of her room. There were no guests at the dinner- table. Although the girl was attractive, nobody noticed her since they were busy eating.

After the meal everybody took a seat in the sitting-room, but the girl would stand up every five minutes and walk up and down in the room as if she was very restless.

In these sections, the evening-meal and the households sitting positions are explained. The girl's nervousness and tediousness is reflected together with the family motif.

Just as everything in the world rapidly comes to an end, the unbearable nervousness of the girl ended after two hours.

The headiness, the girl experienced as the main character in the story, caused by a wave of excitement mixed with joy and elapse of time is expressed with time motif.

Every two minutes she would look at the clock angrily and would curse the time for being late.

Angel's feeling pessimistic and angry about the slow elapse of time is reflected in time motif. She is experiencing a feeling of seesaw between e happiness and pessimism because of elapse of time.

This time they were frustrated and all their sweet dreams turned into a painful, unendurable heart- beat and an ongoing trembling.

As she is secretly trying to run away from home, Anjel has the feeling that she will not be able to fulfill her ambitions and this makes her unhappy. This situation is described together with disappointment motif.

The grief, ill-luck the poor experienced from the very minute after leaving the room, should have been more than enough that the janitor stretches his hand from the window, opens it and pulls the poor inside.

The main character, Anjel, is pessimistic about all the bad experiences she has. Even a very trifle event eradicates all the good things in hurt mind and starts to feel pessimistic. The melancholy motif is exhibited throughout the story.

He would leave a trace along the way so as not lose his directions. For example, he would put little stones, very close to each other, along the direction he followed. He would not miss the stones in the moonlight.

Along the way she was going to meet her lover in the forest, Anjel would leave little stones on the way so as not to be lost on the way back. This section talks about the beauty 
of the moon and the open country in the description of the nature.

I can't call this bad luck, because I found myself in this dilemma. I asked for it. I am in such a hopeless situation that I may dishonour myself.

Anjel meets a shepherd in the forest on her way to meet her lover and she starts to feel very pessimistic with the fear of being caught. This melancholic situation is always keeps Anjel's mind busy throughout the story, and this causes her the worst uneasiness.

Shadows of trees in the moonlight are fearful scenes and the crooked shadows from branches are frightening because they look like the shadows of watchers following them.

The feeling of desperation and confusion experienced here due to meeting secretly and the fear of being caught, is reflected to the nature and the trees look like someone preventing them from meeting.

Yes! A forest! A dreadful place. Among these tall cypress tress, listening the the silence, one feels himself lying in a grave.

The silence of the nature is likened to a grave and this displays the most probable melancholic situation. Likening silence to a grave, reminds us the motif of death.

While everybody is falling asleep in the moonlight, stretched in their comfortable beds, feeling their lovers' hair, I am wondering in the forest just like wild monsters.

Marki describes the forest, where he meets his lover secretly, as a place full of monsters. He feels totally disappointed because of his thoughts. The place, which is full of beauty, is a bad place because of silence and his pessimistic thought.

The young man: Anjel, my love! Yes! My second sould! You were waiting for me in the forest, weren't you?

Anjel: Not only in the forest, but I would never be afraid of waiting for you even in hell.

In Anjel's and Marki's conversation, the motif of love is clearly expressed. This mutual love is, from time to time, is reflected with pleasing words.

During this sweet conversation, their fear is still continuing as the birds fly among tree branches and the sudden image of shadow of the trees that looks like someone watching them.

The fear of being caught, due to Anjel's ongoing negative and pessimistic thoughts, her animating and likening the nature is everywhere in the story. This fear causes anxiety, but not peace when they meet.

Marki, accepting your proposal is not possible. You know that very well. I'll go back to my room, Marki. I'm sorry, but It is not decent to meet in your room right now

Anjel's objection to the meeting place disappoints Marki and they keep crying until the next meeting. In this part also, there is pessimism and tears.

\subsection{Thematic study II: The poem "Süha and Pervin” by Tevfik Fikret}

The poem begins after Süha and Pervin meet in a forest. The nature and the shelter for the two lovers are described in a decent language.

Süha prefers to be in a different place where nobody can reach easily, rather than the one he is in with Pervin. He does not feel comfortable at his present place. This feeling can be noticed on his face (Imagination).

Pervin is worried about Suha's fancy to be at an imaginary place and this worries her. She questions him on his unhappiness with his life (Reality).

Süha imagines himself at an unknown place where he can be happy. The life he wishes for is at a place where he will not be disturbed in his conversations with the sky and God. The running away motif is presented in the theme of an imaginary place.

Good news! The clouds are dispersing. Wow! We did not have the sunshine for days.

Pervin is a realistic character. She likes the sun and light. Süha, on the other hand, reflects his pessimism to the nature and describes it. Even more, Pervin still treats Süha as a 
child.

Treating Süha as a child and voicing it disappoints Süha. This disappointment is hidden in his looks.

Pervin can not put up with Süha's childishness and insists on living real love. Under those prevailing circumstances she wants to live her love freely, but Süha's imaginary character disappoints her.

Reality does not fit Süha's character. For him, regarding love and sex equal means deceiving oneself. Süha and Pervin have different perceptves regarding love (RealisticImaginative).

No matter what Pervin says, Süha is still in an imaginary world. He argues that sadness is a part of his life. The tediousness motif has the priority.

Süha believes that negative thoughts do not give one any harm. He is happy to be in this group. (There is sentimentality, getting pleasure from sadness. Masochism). Trying to prove something becomes an obstacle in understanding life. Thus, we can not notice the beauties of life.

Süha pictures the place he imagines pessimistically as he describes the nature. He describes this place tediously. He enjoys tediousness.

Just like Tevfik Fikret, Süha enjoys being imaginative and he relates this characteristic to his nature.

Süha wants to die. He hopes that he can be with his love next to his grave even after death. This displays the death motif.

\subsection{Stylistic study I: Ahmed Tevfik Efendi}

Ahmed Tevfik Efendi has several poems written in satirical and humorous styles. He includes local expressions and idioms in his poems and writings. His poems usually have an addressing style. From time to time, he includes imitative styles in his writings [1]. In his story, "Bir Manzara-i Dil-Güşa" A.Tevfik Efendi uses Arabic and Persian words, but they are easy to understand. These foreign words are scattered around in certain parts of the story and they can be worked out easily. The main characters in the story have Western names.

\subsection{Stylistic study II: Tevfik Fikret}

As a poet using synonyms, Tevfik Fikret uses Turkish, Arabic, and Persian words corresponding to the same feelings, the same beings, and the same thoughts in his work. He tries art of speech in poetry language to convey an expression and concept in a more effective, intensive, and aesthetic way. He frequently includes in his work natural symbols and considers the nature as a shelter. According to Mehmet Kaplan. Tevfik Fikret is a paradoxical poet. The words, reality-lie, darkness- light prove this issue. The writer is very strict about dictation marks in his poems. At first look, his style seems incomprehensible because of the foreign words he uses [4]. In general he deals with the fear of reality, the rest of the world, timidness, and imagination even if it is deceptive. This can be observed in the poem "Süha and Pervin". In Tevfik Fikret's style there is an image of "trembling", which has an important feature.

\section{Conclusion}

In his poem "Süha and Pervin", Tevfik Fikret displays his view of life and perceptions in an allegoric and symbolic style. There are ample themes full of sadness and pessimism. In 
Tevfik Fikret's work there is reality-fantacy contradiction, and the difference between the two lovers' thoughts and characters. On the other hand, melancholy-pessimism theme stand out. In both works the nature is described with the feeling of pessimism and sadness and as the symbol of love [5]. When the place for the topic and the dialogue between the two lovers are considered, a striking similarity between the two Works can easily be noticed. In this regard, Ahmed Tevfik Fikret Efendi might have been influenced by Tevfik Fikret's Work. One of the two differences between them is that in Tevfik Fikret's Work Süha is the pessimistic character, whereas in Ahmed Tevfik Fikret's Work Anjel is the pessimistic character. The second difference is that in Tevfik Fikret's Work, Süha is deserted because of his being pessimistic, but in Ahmed Tevfik Efendi's Work both lovers leave each other in pessimism and sadness to meet again.

As we study their style, we can observe that Ahmed Fikret Efendi's Work is more comprehensible compared to Tevfik Fikret's Work and this is because A.Tevfik Efendi used foreign words and the language is clearer. Tevfik Fikret, on the other hand, had a more arty style. That is, Ahmed Tevfik Efendi included more public language.

\section{References}

1. Emin Onuş, Ahmed Tevfik Efendi’nin Teselya Savaşı Ile Ilgili Yazıları ve Şiirleri, Doğu Akdeniz Üniversitesi Yüksek Lisans Tezi, 10, (2012).

2. Harid Fedai, Kıbrıs Türk Kültürü Makaleler 1, SAMTAY Mağusa Tarihini Araştırma ve Yazın Vakfi Yayımı, 104-115, (2004).

3. İnci Enginün, Yeni Türk Edebiyatı Tanzimat'tan Cumhuriyet'e (1839-1923), DergâhYayınlar1, 533-534,535-538, (2014).

4. İsmail Parlatır,Tevfik Fikret, Akçağ Yayınları,100-120, (2014).

5. Macit Balık, Sühâ Ve Pervîn”De Narsist Kimliğin Görünümleri, Akademik Sosyal Araştırmalar Dergisi,Yı1: 3(11),Tevfik Fikret Özel Sayıs1. 160-175, (Nisan 2015).

6. Oğuz Karakartal, Tevfik Fikret'in İzinde İki Şair Avram Naon ve İsak Ferera, Eren Yayınc1lık,50-51,(2006).

7. Şevket Öznur, Kıbrıs Türk Edebiyat1, 50-51, (2014).

8. Sevim Şermet, Serbest Şiirin Tarihine Girişte Unutulan Bir Isim: Nurettin Ferruh ve Siir Sanatı,(Turkish Studies International Periodical For the Languages, Literature and History of Turkish or Turkic Volume 5/2 Spring,160-175, (2010). 